\title{
ECOLOGY OF THE GREAT SANDHILLS AND CYPRESS HILLS PLATEAU
}

by Jan Looman, Research Station, Canada Department of Agriculture, Swift Current

[On June 10-11, 1967 the Saskatchewan Natural History Society will hold its annual Summer Meeting at Swift Current. The following short article describes the area to which field trips have been planned.]

The Great Sandhills extend east from the Saskatchewan-Alberta border to approximately north of Tompkins. In Alberta a smaller dune area, the Middle Sandhills, is separated from the Great Sandhills by the South Saskatchewan River and a narrow strip of loamy soils. East of the Great Sandhills, small dune areas of the same formation extend as far east as Highway No. 4 north of Swift Current.

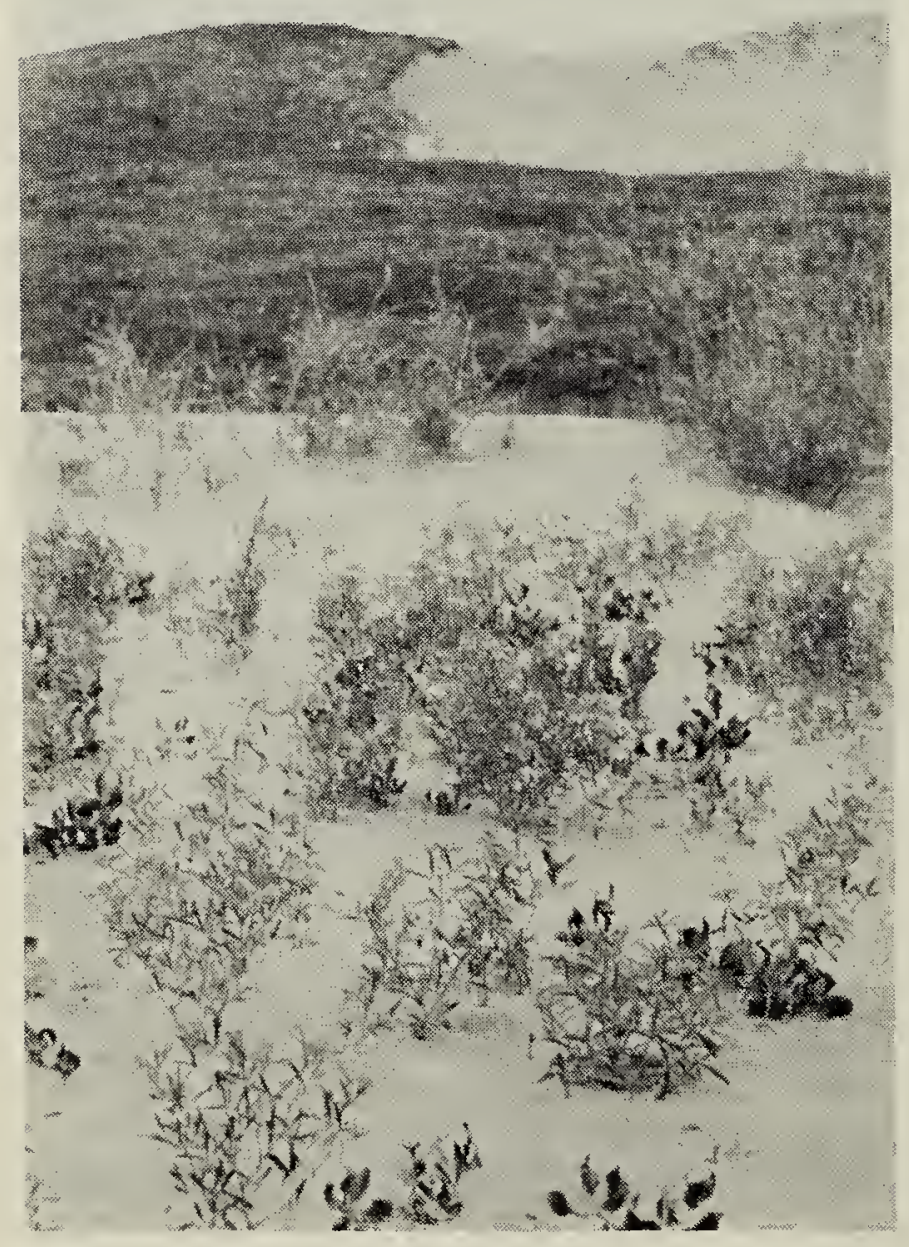

Figure 1. Bare dunes and fairly dense vegetation exist within a short distance of each other in the Great Sandhills.
The sand which forms the dunes is very fine and the absence of even small pebbles shows the aeolian character of the formation. The sand is of glacial origin; repeated reworking by wind and water have caused its present homogeneous texture. Though very dry and often very hot at the surface, the dune landscape is relatively well supplied with sub-surface water. Even in the middle of summer the sand is moist at a shallow depth, usually within the upper foot. A remarkable phenomenon in the dune landscape is the existence of almost bare dunes and fairly dense vegetation within a short distance of each other (Figure 1).

The dune landscape may be visualized as being at first a smooth layer of sand over loam or clay. The sand lets water percolate through very readily, but this water does not penetrate easily into the heaviertextured loam or clay. As a result, grasses and herbs, shrubs and trees establish readily. Where the loam or clay underlies the sand at a shallow depth, and relatively little water is held the grasses and herbs will predominate. Shrubs and trees establish in the deeper sand layers.

In periods of drought the areas occupied by grassland become desiccated; the upper layers of the sand start drifting and the sand piles up against shrubs, forming "embryonic" dunes. This process is repeated over and over again, and because several shrubs have the ability to keep growing above the sand the embryonic dunes become higher and higher, eventually becoming hills.

Obviously, this process is a very effective force in the selection of species especially equipped to survive in so rigorous an environment. In an active dune landscape several species 
ccur which are rarely found elsehere, partly because they are the nly ones capable of survival in this nvironment, but also partly because his "specialization" has made them oorly equipped for competition in hore amenable environments. Most of he species well adapted for survival $h$ the dunes are perennials, many of hich have very extensive rootstocks. - Sspecially the rootstocks of Psoralea inceolata (lance-leaved psoralea) an reach astounding lengths. Several ther species, of which Oryzopsis hylenoides (Indian rice grass) is an xample, have the ability to root at he nodes and thus produce a kind of vertical" rootstock. The annuals, like upinus pusillus (small lupine) and ygodesmia rostrata (annual skeleonweed), have seedlings which can ush up through an inch or more of and, become buried, and push their ay through once more.

The sand is very low in nutrients, ut the high permeability of even very eep sand-layers results in the accupulation of large amounts of nutrients n low-lying areas. As a result, the une landscape can become very varied, with the sparsely vegetated dunes, dry and poor sand flats, and the richer, more moist flats each supporting its own typical vegetation. In especially favourable locations shrubs and trees flourish, including Amelanchier alnifolia (saskatoon) and Prunus melanocarpa (black-fruited chokecherry), and offer food and shelter for the White-tailed Deer, as well as many species of birds.

The fauna includes the Pronghorn, probably the Kangaroo Rat, and many species of birds. However, not being a zoologist, this writer prefers to avoid entering into details. Apparently, the zoology of the Great Sandhills is relatively poorly known.

The Cypress Hills Escarpment is a strong contrast to the Sandhills. Whereas the substrate in the Sandhills is of a highly uniform texture, and of approximately uniform age, in the escarpment there are coarsetextured materials (Figure 2) and the successive deposits that are exposed span a period of some 60,000 ,000 years. The oldest exposed layers belong to the Whitemud and Frenchman formations, dating back to the

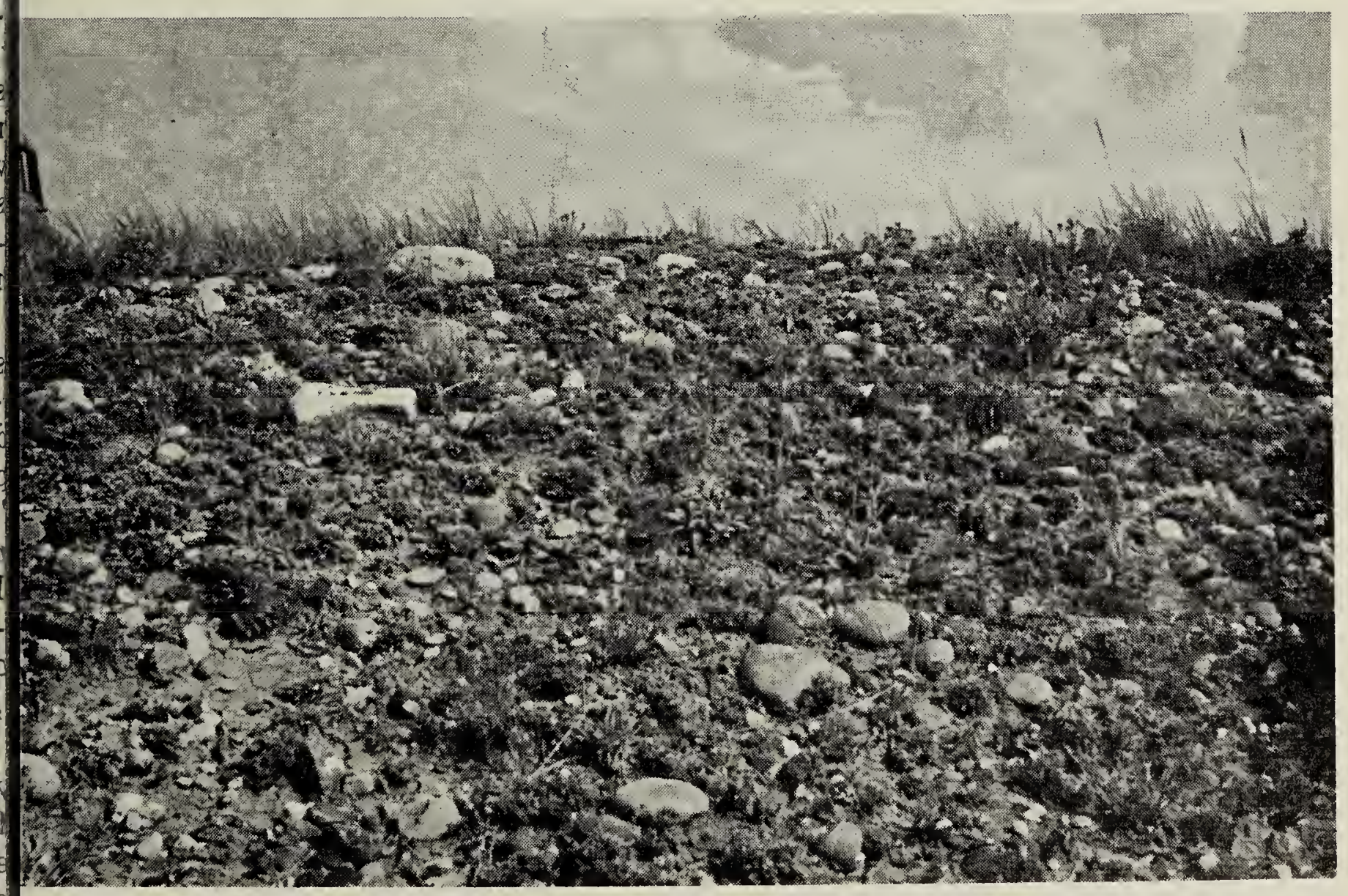

Figure 2. Coarse-textured substrate of the Cypress Hills Escarpment. 


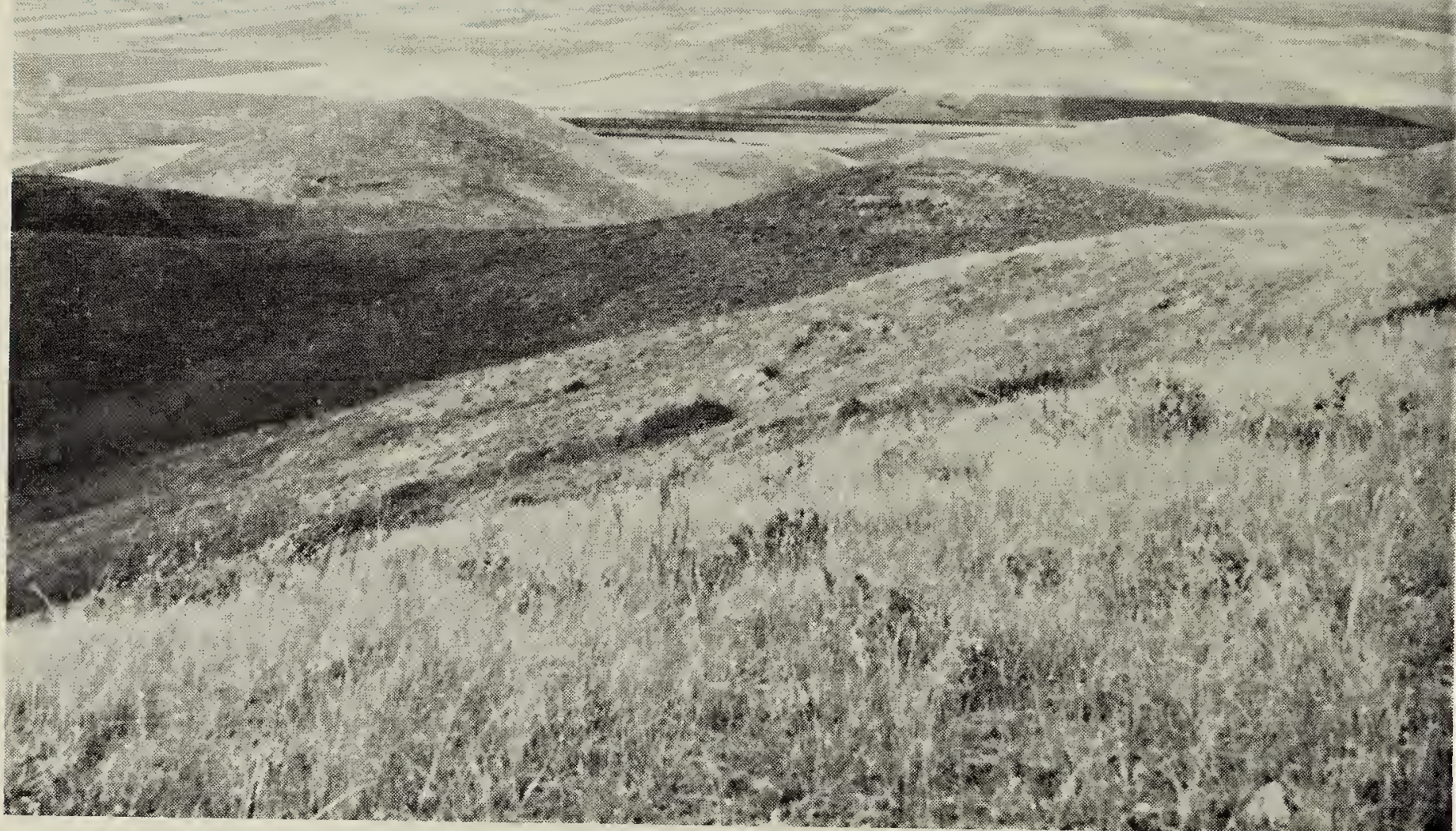

Figure 3. Panoramic view of the farming areas north of the Cypress Hills Escarpment.

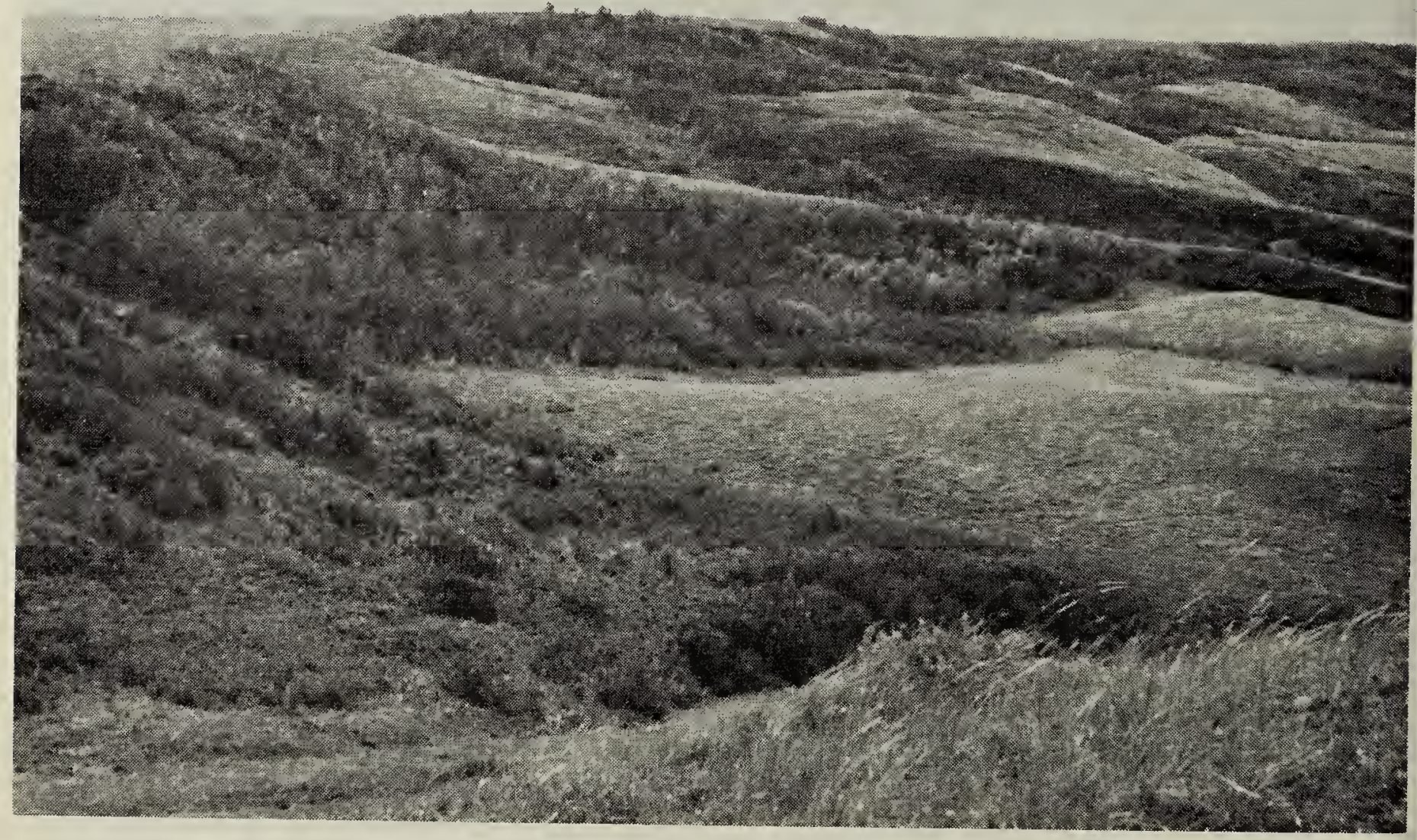

Figure 4. Trees and shrubs in the coulees of the Cypress Hills Escarpment. 
Jpper Cretaceous. The Frenchman leposits are mostly of the clay-phase, ecognizable by its "popcorn" strucure when dry. Overlying the Frenchnan are the Ravenscrag formation of aleocene age and the Cypress Hills ormation, dating back to the Oligoene. In many places the glacial deleposits overlying the Cypress Hills ormation have been eroded away, eaving the older deposits exposed. Where the often very gravelly $\mathrm{Cy}$ oress Hills formation is exposed exremely dry habitats are thus created.

The Whitemud and Frenchman fornations have been the source of many Dinosaur fossils in the southern part $f$ the escarpment at Eastend; the Ravenscrag and Eastend formations lo not have Dinosaur remains, but ave yielded mammalian fossils.

The escarpment rises about 850 feet bove the plains to the north and gives a beautiful panoramic view of the farming areas (Figure 3). A.t the ame time the altitude of about 3,300 eet brings the Stipa prairie of the plains in contact with the montane Fescue grassland. As a result, several sub-montane species are found in the grassland. Among others are Sedum stenopetalum (narrow-petaled stonecrop), Potentilla fruticosa (shrubby cinquefoil), Delphinium bicolor (low larkspur), and Arenaria lithophila (rocky-ground sandwort).

In eroded areas several rather rare plant species occur, most of which are "cushion" plants, well adapted to the harsh environment: Astragalus caespitosus (tufted milk-vetch), Townsendia sericea (low townsendia), Erigeron radicatus (dwarf fleabane) and $E$. compositus (compound fleabane) are found, usually together with the more common species like Eriogonum flavum (yellow umbrella plant) and Astragalus triphyllus (cushion milkvetch). This plant community is typical of the highly calcareous and extremely harsh habitat, but at the same time one of the most colorful.

In the many coulees, shrubs and trees are plentiful (Figure 4), but while the grassland is very different from that in the Sandhills, most of the species of shrubs and trees here are the same as those found in the Sandhills.

The fauna of the area cannot be described in detail, though it may be mentioned that Pronghorn and Whitetailed Deer are in the area, as well as several birds not seen in the Sandhills.

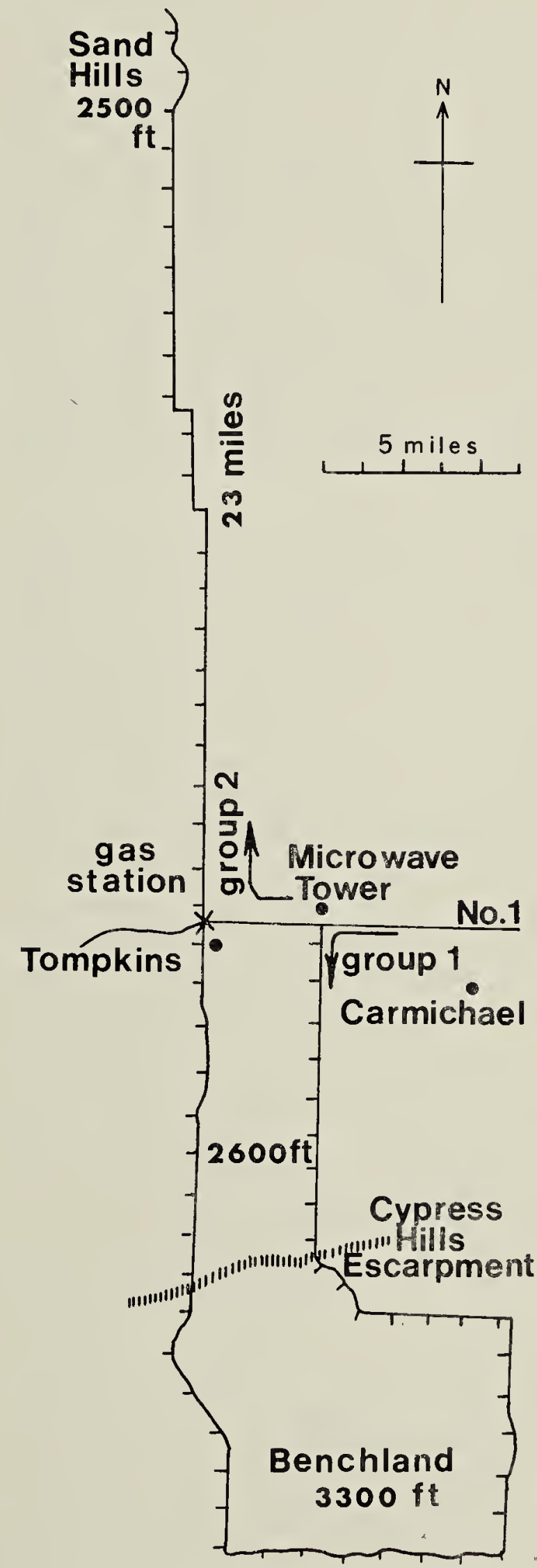

Summer Meeting field trips, June 10-11, 1967 